\title{
molecules
}

ISSN 1420-3049

http://www.mdpi.org

\section{Structures and Chemical Equilibria of Some N-Heterocycles Containing Amide Linkages}

\author{
M. S. Masoud, M. Abd El Zaher Mostafa*, R. H. Ahmed and N. H. Abd EI Moneim \\ Department of Chemistry, Faculty of Science, Alexandria University, Ibrahimia, P.O. Box 426, \\ Alexandria 21321, Egypt; Fax: (+20) 3-3911794 \\ * Author to whom correspondence should be addressed; e-mail: dr_abdel_zaher@hotmail.com
}

Received: 3 July 2000; in revised form 12 January 2003 / Accepted: 15 April 2003 / Published: 31 May 2003

\begin{abstract}
Structures and chemical equilibria of 5-carboxy-2-thiouracil (1), 5,6-diphenyl3-hydroxy-1,2,4-triazine (2), 1-phenyl-3-methyl-5-pyrazolone (3) and 2-mercapto-4,6dimethylpyrimidine hydrochloride (4) are reported. Their electronic transitions are assigned and $\mathrm{pK}$ values are evaluated and discussed.
\end{abstract}

Keywords: Chemical equilibria, 5-carboxy-2-thiouracil, synthesis, electronic transitions and $\mathrm{pK}$ values.

\section{Introduction}

Nucleic acid and nucleic acid derivatives are multisite ligands. The interaction of these molecules with both natural and foreign metal species has stimulated great interest [1]. These biomolecules are of importance in enzyme reactions that require or act on nucleic acid constituents and the structures of nucleic acid-protein complexes [2]. There are several conformational aspects of the geometry of the nucleosides and nucleotides where the possibility that the bases will stack and hydrogen bonding interactions dominate $[3,4]$. Some of these compounds inhibited the replication of bacterial DNA selectively, completely and reversibly [5,6]. Some of these are used as anti-cancer agents [7]. 
In our laboratory, Masoud et al. have published a series of papers that throw light on the chemistry of pyrimidine compounds and their complexes [8-17]. The aim of this paper is to study the structural chemistry and the chemical equilibria of the compounds 5-carboxy-2-thiouracil (1), 5,6-diphenyl-3hydroxy-1,2,4-triazine(2),1-phenyl-3-methyl-5-pyrazolone (3) and 2-mercapto-4,6-dimethylpyrimidine hydrochloride (4). Uracils are studied from different structural chemistry points of view. The most important recent reviews are given [18-21].

\section{Results and Discussion}

\section{Effect of pH on the Electronic Absorption Spectra of the Studied N-Heterocycles}

This study is undertaken to gain some insight about the species that might be formed in solutions of different $\mathrm{pHs}$, to explain the mechanism of ionization of such compounds and to evaluate their dissociation constants. The latter are readily obtained from the absorbance-pH curves by application of the half height [22], modified limiting absorption [23] and Colleter methods [24].

The electronic absorption spectra of orotic acid gave two bands at 210 and $280 \mathrm{~nm}$ with a pKa of 9.3 and an isobestic point at $286 \mathrm{~nm}$. Both bands are due to $\pi-\pi^{*}$ and $\mathrm{n}-\pi^{*}$ electronic transitions, respectively.

Also, the UV spectrum of thiouracil gave two bands at 210 and $270 \mathrm{~nm}$ in the $\mathrm{pH}$ range 2-7 due to the $\pi-\pi^{*}$ transition, and a new band at $255 \mathrm{~nm}$ in the $\mathrm{pH}$ range 9-12. The position and intensity of this band is almost $\mathrm{pH}$ independent. The spectra gave a $\mathrm{pKa}$ value of 8.2 with the liberation of one proton due to the ionization of SH group.

Orotic acid has three potentially dissociable groups as indicated by conductometric titration [25] with $\mathrm{pK}$ values as follows: $\mathrm{pK}_{1} \sim 2.8, \mathrm{pK}_{2} \sim 9.45$ and $\mathrm{pK}_{3}>13[26,27]$. The first ionization is due to the carboxylic group and the second is obtained by elimination of a second proton from $\mathrm{N}(1)-\mathrm{H}$ or $\mathrm{N}(3)-\mathrm{H}$.

In the electronic absorption spectra of $1 \times 10^{-4} \mathrm{M} 5$-carboxy-2-thiouracil (1), in the pH range 2.0311.03 three characteristic bands are observed at 210, 270 and $308 \mathrm{~nm}$, with $\varepsilon$ values that lie in the ranges $6900-18500,9300-12700$ and $12600-16500$, respectively. The first band is probably due to a $\pi-\pi^{*}$ of the two $\mathrm{sp}^{2}$ hybridized carbons of the exocyclic band in heterocyclic ring. The second band is assigned to the coupled $\pi-\pi^{*}$ of the two carbonyl and thiocarbonyl groups in the $\beta$-position [28], and may be considered to be due to intramolecular hydrogen bond formation between $\mathrm{N}(3)-\mathrm{H}$ with $\mathrm{C}=\mathrm{O}$ and $\mathrm{N}(1)-\mathrm{H}$ with $\mathrm{C}=\mathrm{S}$ [29]. The position of the first band is $\mathrm{pH}$ independent while its intensity increases up to $\mathrm{pH} 7.99$ then decreases. The second band is more intense in acidic solutions and becomes less intense in neutral and basic solutions. The position of this band is independent of the $\mathrm{pH}$ over the range studied (2.03-7.01). In basic medium, this band is slightly shifted and decreased in intensity probably due to the formation of a protonated species overlapped with the $\pi-\pi^{*}$ electronic transition of uracil ring. However, the third band, due to presence of $\mathrm{COOH}$ group, is blue shifted in the $\mathrm{pH}$ range 2.03-7.01 but with the same intensity. This behavior suggests a tautomerism between the thione and thiol structures. When the $\mathrm{pH}$ is increased the band is strongly red shifted as a result of 
proton elimination. In addition to the former three bands, a new band appeared in the $\mathrm{pH}$ range 7.9911.03 at $229 \mathrm{~nm}$ with $\varepsilon$ values $6300-9800$, representing the shift of the tautomeric equilibrium towards the enol form in basic solutions. The intensity of this band decreases as the $\mathrm{pH}$ increases. Three welldefined isobestic points appeared at 219, 306 and $324 \mathrm{~nm}$. The first covers the $\mathrm{pH}$ values 3.13-4.99, 9.01, 10.02, the second covers the $\mathrm{pH}$ values 3.13-4.99, 7.01-10.02 and the third one is for the $\mathrm{pH}$ values 2.03-4.03, 7.99, 9.01. The isobestic points assign the presence of different absorbing species in equilibrium to each other [30], i.e., the $\mathrm{HN}(1) \mathrm{C}=\mathrm{S}$ and $\mathrm{HN}(3) \mathrm{C}=\mathrm{O}$ groups are subjected to simultaneous ionization.

Methods Applied to Calculate the $\mathrm{pK}$-values from the Absorbance - pH Relationship:

a) Half Height Method [22]

At a constant wavelength, the $\mathrm{pK}$ value of the compound can be evaluated (where half of the compound exists in the ionized form and the other half in the nonionized). It is known that:

$$
p H=p K+\log \frac{A s_{1 / 2}}{A s_{\max }-A s_{1 / 2}}+\log \gamma
$$

$(\gamma=$ activity coefficient term and controlled by ionic strength of a supporting electrolyte), i.e., at half height of the As-pH curves, the pK-values data are collected in Table 1.

b) Modified Limiting Absorption Method [23]:

For an organic compound of formula $\mathrm{H}_{\mathrm{n}} \mathrm{A}$, the first ionization for the ligand takes place as follows:

$$
\begin{gathered}
\mathrm{H}_{\mathrm{n}} \mathrm{A} \rightleftharpoons \mathrm{H}_{\mathrm{n}-1} \mathrm{~A}^{-}+\mathrm{H}^{+} \\
p H=p K_{1}+\log \gamma+\log \frac{\left(A s-A s_{\text {min }}\right)}{\left(A s_{\text {max }}-A s\right)}
\end{gathered}
$$

When plotting the log absorbance ratio term versus $\mathrm{pH}$, a straight line is obtained. The $\mathrm{pK}_{1}$ value is computed when the log absorbance ratio value equals zero. The data are collected in Table 1. The slope (n) of such line gives the number of the ionized protons.

c) Colleter Method [24]:

This method is widely recognized for evaluation of the pK values of different classes of compounds. The calculation is applied on the basis that, for three values of absorbance at different $\mathrm{H}^{+}$, the following equation is applied:

$$
K a=\frac{\left[H_{2}^{+}\right]-M\left[H_{3}^{+}\right]}{M-1}
$$


Where:

$$
M=\frac{A s_{3}-A s_{1}}{A s_{2}-A s_{1}} \cdot \frac{\left[H_{1}^{+}\right]-\left[H_{2}^{+}\right]}{\left[H_{1}^{+}\right]-\left[H_{3}^{+}\right]}
$$

The absorbance values used in the calculations are selected from As-pH plots. The data are collected in Table 1.

Table 1: Dissociation Constants (pKa) of the Organic Compounds at $\lambda=335 \mathrm{~nm}$.

\begin{tabular}{|l|c|c|c|c|}
\hline Compound & Half Height & Modified Limiting & Colleter & n \\
\hline 5-Carboxy-2-thiouracil (1) & 4.7 & 4.7 & 4.8 & 1.0 \\
& 7.7 & 7.9 & 8.0 & 1.0 \\
5,6-Diphenyl-3-hydroxy-1,2,4-triazine (2) & 4.3 & 4.4 & 4.1 & 0.5 \\
& 7.6 & 7.5 & 7.5 & 1.0 \\
1-Phenyl-3-methyl-5-pyrazolone (3) & 8.1 & 7.9 & 8.1 & 1.0 \\
& & & & \\
2-Mercapto-4,6-dimethylpyrimidine & 3.6 & 3.6 & 3.5 & 1.0 \\
hydrochloride (4) & 8.1 & 8.3 & 8.3 & 1.0 \\
\hline
\end{tabular}

For 5-carboxy-2-thiouracil (1) two pKa values were evaluated at $335 \mathrm{~nm}$. The $\mathrm{pKa} \mathrm{a}_{1}$ of 4.7 with the liberation of one proton through ionization is probably due to the removal of a proton from the $\mathrm{COOH}$ group [31]. The $\mathrm{pKa}_{2}$ value of 7.8 with the liberation of a proton may be from the 2-SH group or the 4-OH group, where two modes of ionization could be represented:

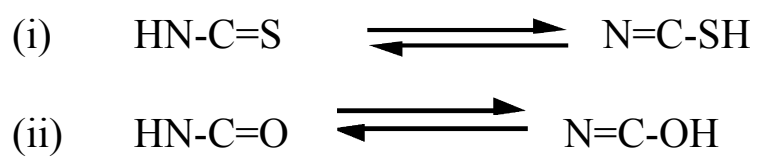

The negative ferric chloride test for phenolic-OH and the $\mathrm{pKa}$ value lower than that reported for phenolic compounds [32] lead us to argue that the mode of ionization (i) is more acceptable than (ii). Thus the ionization process is assumed to proceed as indicated in Scheme 1.

Similarly, in the electronic absorption spectra of $1 \times 10^{-4} \mathrm{M}$ 5,6-diphenyl-3-hydroxy-1,2,4-triazine (2) in solutions within the $\mathrm{pH}$ range $3.13-11.03$, three electronic absorption bands appear at 216, 250 (both are intense) and $341 \mathrm{~nm}$ (broad) with $\varepsilon$ values 6700-12600, 5300-12600 and 1600-4800, respectively. The first two bands are probably due to the $\pi-\pi^{*}$ transition while the third band may be due to intramolecular hydrogen bond between $\mathrm{N}(2)-\mathrm{H}$ or $\mathrm{N}(4)-\mathrm{H}$ with $\mathrm{C}=\mathrm{O}$ [29] .

When the $\mathrm{pH}$ increases in the 2.03-6.19 range, the intensity of the two bands at 216 and $250 \mathrm{~nm}$ decreases while the third one becomes more intense. However, the positions of these bands are $\mathrm{pH}$ independent. With a further increase of the $\mathrm{pH}$ to 11.02 , the three bands become more intense with a slight red shift in the second and third bands. 


\section{Scheme 1}<smiles>O=C(O)c1c[nH]c(=S)[nH]c1=O</smiles><smiles>O=C(O[14c]1ccccc1)c1cnc(S)nc1O</smiles>

Two isobestic points are seen at 288 and $318 \mathrm{~nm}$. The first covers the $\mathrm{pH}$ values 4.03, 7.99-11.03 and the second one covers the $\mathrm{pH}$ values 7.99-11.03, indicating the presence of an equilibrium between different species in the basic media. Two pKa values were evaluated (4.3 and 7.6) at $\lambda=355$ $\mathrm{nm}$ with the liberation of one proton in each step. The first one is due to the associated species $\mathrm{H}_{2} \mathrm{~L}_{2}$ with $n$ value of 0.5 . The negative ferric chloride test reaction and the lower $p K a$ value (7.6) than that of the reported for phenolic compounds [32] assumed that the second proton is liberated from 4-NH or 2NH groups and not from 3-OH group. The following mechanism of ionization is suggested:

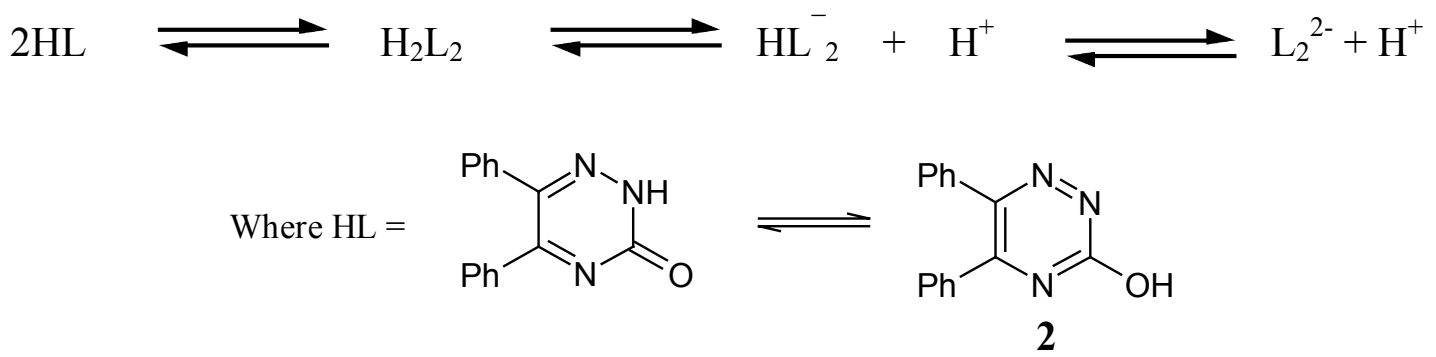

On the other hand, in the electronic absorption spectra of $1 \times 10^{-4} \mathrm{M}$ 1-phenyl-3-methyl-5pyrazolone (3), in solutions within the $\mathrm{pH}$ range $2.01-7.37$, one electronic absorption band appeared at $245 \mathrm{~nm}$ with $\varepsilon$ values in the range 13900-16600, which is $\mathrm{pH}$ independent both in intensity and in position. On increasing the $\mathrm{pH}$ up to 9.12 , two more bands appeared at 209 and $344 \mathrm{~nm}$ with $\varepsilon$ values 1300-13900 and 1000-3400, respectively. The two bands at 209 and $245 \mathrm{~nm}$ become less intense on going from $\mathrm{pH} 8.13$ to 9.12 while the $344 \mathrm{~nm}$ band becomes more intense. At the pHs 10.06 and 11.01, the first band disappeared, the second one becomes slightly more intense while the third band becomes less intense and broader. Accordingly, 1-phenyl-3-methyl-5-pyrazolone (3) exists in the keto form in acidic, neutral and strong basic solutions, however, it exists in the enol form only in solutions with $7.37<\mathrm{pH}<10.06$. 
Two well-defined isobestic points appeared at $242 \mathrm{~nm}$ (covering the $\mathrm{pH}$ 's 3.58, 9.12, 10.06) and $275 \mathrm{~nm}$ (covering the pH's 3.58, 7.37, 8.13, 9.12) to indicate the presence of different absorbing species in equilibrium. One pKa value of 8.1 was evaluated at $335 \mathrm{~nm}$ in the basic medium $(7.37<\mathrm{pH}$ $<10.06$ ) with the liberation of one proton which may be (a) from the 2-NH group, or (b), the 5-OH group, where two modes of ionization could be presented (Scheme 2).

\section{Scheme 2}

(i)<smiles>Cc1cc(=O)n(-c2ccccc2)[nH]1</smiles><smiles></smiles>

(ii)

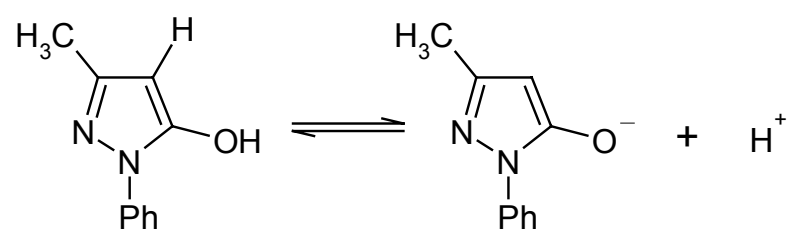

The positive ferric chloride test reaction for phenolic-OH and the closeness of the pKa value to that reported for phenolic compounds [32] lead us to propose that the mode of ionization (ii) is more acceptable than (i). Therefore the ionization process is assumed to proceed as indicated in Scheme 3:

\section{Scheme 3}<smiles>CC1=NN(P(#P)c2ccccc2)C(=O)C1</smiles>

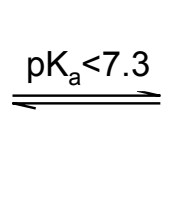
3<smiles></smiles><smiles></smiles><smiles>Cc1cc([O-])n(-c2ccccc2)n1</smiles>

The electronic absorption spectra of $1 \times 10^{-4} \mathrm{M} 2$-mercapto-4,6-dimethylpyrimidine hydrochloride (4), in the 2.00-11.03 pH range displayed three electronic absorption bands at 216, 274 and $331 \mathrm{~nm}$ with $\varepsilon$ values amount 3200-10400, 16700-20800 and 1600-5100, respectively. In the pH 2.00-4.99 range, the first band becomes more intense and as the $\mathrm{pH}$ increases, it becomes broad and less intense. However, in the $\mathrm{pH}$ 2.00-7.37 range, the second one is $\mathrm{pH}$ independent, both in intensity or in 
position, while it becomes less intense with a slight blue shift in the $\mathrm{pH}$ 8.13-11.01 range. Meanwhile, the intensity of the third band increases in the $\mathrm{pH} 2.00-4.99$ range, then decreases as the $\mathrm{pH}$ increases stepwise, until it completely vanishes in strong basic media. Two isobestic points appear at 268 and $272 \mathrm{~nm}$. The first covered all the $\mathrm{pH}$ range, while the second one covers the $\mathrm{pH}$ values 2.00-7.37, 11.01. However, two pKa values were evaluated (3.5 and 8.1), with the liberation of one proton in each step. The ionization mechanism seen in Scheme 4 is proposed:

\section{Scheme 4}<smiles>Cc1cc(C)nc(S)n1</smiles><smiles>Cc1cc(C)nc(S)n1</smiles><smiles>CC=CC</smiles>

\section{Conclusions}

We have studied structures and chemical equlibria of 5-carboxy-2-thiouracil (1), 5,6-diphenyl-3hydroxy-1,2,4-triazine (2), 1-phenyl-3-methyl-5-pyrazolone (3) and 2-mercapto-4,6-dimethylpyrimidine hydrochloride (4). The $\mathrm{pKa}$ values of such compounds were determined by different methods and their different modes of ionization were determined.

\section{Experimental}

\section{General}

Ultraviolet and visible spectra were recorded using a Perkin-Elmer Model Lambda 4B spectrophotometer covering the wavelength range 190-900 nm. Infrared spectra (KBr disks) were made using a Perkin-Elmer Model 1430 Spectrophotometer covering the frequency $200-4000 \mathrm{~cm}^{-1}$. Uracil and 2-thiouracil were purchased from BDH, while 5-carboxy-2-thiouracil was from SIGMA. These highly purified compounds were used without further purification. Their purity was checked by m.p. and comparison of some of their physical properties, e.g., solubility and colour. Universal buffer solution was prepared by taking $0.04 \mathrm{M}$ each of $\mathrm{H}_{3} \mathrm{BO}_{3}, \mathrm{H}_{3} \mathrm{PO}_{4}$ and $\mathrm{CH}_{3} \mathrm{COOH}$ acids and adding the required volume of $0.2 \mathrm{M}-\mathrm{NaOH}$ to give the desired $\mathrm{pH}$ [36]. The $\mathrm{pH}$ was checked by using a Jenuay 
$3015 \mathrm{pH}$-meter, previously calibrated with standard buffer solutions of $\mathrm{pH} 4.00,7.02$ and 9.18. $\mathrm{KCl}$ solution $(0.10 \mathrm{M})$ was prepared and used to adjust the ionic strength of the solutions. Carbon, hydrogen, nitrogen and sulphur contents of all the synthesized products were analyzed at the Central Laboratory, Faculty of Science, Alexandria University, Alexandria - Egypt, and all compounds gave satisfactory elemental analysis.

\section{Syntheses of the Compounds Studied}

5,6-Diphenyl-3-hydroxy-1,2,4-triazine (2). A mixture of benzil $(10.5 \mathrm{~g})$ in acetic acid $(100 \mathrm{~mL})$ and semicarbazide hydrochloride $(7 \mathrm{~g})$ in water $(20 \mathrm{~mL})$ was heated under reflux for $3 \mathrm{~h}$. The reaction mixture was poured onto cold water with stirring and the product obtained was filtered off, washed with water and dried to give $9 \mathrm{~g}$ of crude product, which was recrystallized from ethanol to give needles of pure material having m.p. $225^{\circ} \mathrm{C}$ (lit. [33] $224-225^{\circ} \mathrm{C}$ ).

1-Phenyl-3-methyl-5-pyrazolone (3). A mixture of ethyl acetoacetate (13 $\mathrm{mL}, 0.1 \mathrm{~mole})$, phenylhydrazine $(10.8 \mathrm{~mL}, 0.1$ mole) and glacial acetic acid $(25 \mathrm{~mL})$ was heated under reflux for $6 \mathrm{~h}$. The reaction mixture was concentrated under vacuum whereupon a yellow precipitate (13 g) was formed. It was recrystallized from hot water to give yellowish prisms of the title compound, m.p. $126-128^{\circ} \mathrm{C}$ (lit. [34] $127^{\circ} \mathrm{C}$ )

2-Mercapto-4,6-dimethylpyrimidine hydrochloride (4) [35]. Concentrated hydrochloric acid (25 $\mathrm{mL})$ was added to a suspension of finely-powdered thiourea $(7.6 \mathrm{~g}, 0.1 \mathrm{~mole})$ in acetylacetone $(12 \mathrm{~g}$, 0.12 mole $)$ and ethanol $(250 \mathrm{~mL})$. The mixture was boiled under reflux for $2 \mathrm{~h}$. After cooling, the yellow needles of the title compound were collected, m.p. $190-195^{\circ} \mathrm{C}$.

\section{References:}

1. Berliner, L. J.; Wong S. S. Biochem. 1975, 14, 4977.

2. Lungquist, S.; Lindahl,T. J. Biol. Chem.1974, 249, 1530.

3. Chang, C. H.; Marzilli, L. G. J. Am. Chem. Soc., 1967, 96, 3656.

4. Gould, I.R.I.; Hillier, I. H. J. Chem. Soc. Perkin Trans. II, 1990, 329.

5. Brown, C. N. J. Mol. Biol. 1971, 59, 1.

6. Brown, C. N.; Wisseman,L. C. Nature. 1972, 237, 72.

7. Urena, F. H.; Carretero, M.N.M.; Peregrin, J.M.S.; Lopez, G.A.C. Trans. Met. Chem. 1995, 20, 262.

8. Masoud, M.S.; Zaki, Z. M.; Ismail, F. M.; Mohamed, A.K. Z. Für Phys. Chem. (N.F.) 1994, 185, $S, 223$.

9. Masoud, M.S.; Abd El-Hamid, O. H.; Zaki, Z. M. Trans. Met. Chem. 1994, 19, 21.

10. Masoud, M.S.; Haggag, S. S.; Zaki, Z. M.; El-Shabasy, M. Spectroscopy Letter. 1994, $27,775$. 
11. Masoud, M.S.; El-Nahas, H. M.; Haggag, S.S. Pak. J. Sci. Ind. Res. 1995, 38, 108.

12. Masoud, M.S.; Haggag, S.S.; Abd El Hamid, O. H. Rev. Roum. Chim. 1996, 41, 21.

13. Masoud, M.S.; Hasanien, A. A.; Ghonaim, A. K.; Khalil, E. A.; Mahmoud, A. A. Z. Für Phys. Chemie, Bd. 1999, 209, S, 223.

14. Masoud, M.S.; Hindawy, A. M.; Ahmed, R. H. Pak. J. Sci. Ind. Res. 1999, 42, 11.

15. Masoud, M.S.; Khalil, E. A.; Ibrahim, A. A.; Marghany, A. A. Z. Für Phys.Chemie. 1999, $211,13$.

16. Masoud, M.S.; Hammud, H. H. Ultra Sci. Phys. Sci., 2000, 12, 12.

17. Masoud, M.S.; Ghonaim, A. K.; Ahmed, R. H.; Abou El-Enein, S. A.; Mahmoud, A. A. J. Coord. Chem. 2002, 55, 79.

18. Ahmed, Z.A. Delta, J. Sci. 1994, 18, 55; [Chem. Abst. 1997, 127, 99652 q].

19. Arora, C.B.; Rastogi, R.; Awasthi, U.; Krishna. Asian J. Phys. 1996, 5, 231; [Chem. Abst. 1997, $126,258042 \mathrm{p}]$.

20. Gupta, J.K.; Kumar, S.; Kumar, S.; Kaushik, S.D. Asian J. Phys. 1996, 5, 245; [Chem. Abst. 1997, $126,271398 \mathrm{~d}]$.

21. Khan, B.T.; Khan, S.R.A.; Annapoorna, K. Indian J. Chem. Sect. A; Inorg. Bioinorg., Phys., Theor. Anal. Chem., 1995, 34A, 878 [Chem.Abst. 1995, 123, 357535 w].

22. Issa, R. M. J. Chem. U. A. R. 1971, 14, 113.

23. Muck, A. A.; Pravico, M. B. Anal. Chim. Acta. 1969, 45, 534.

24. Colleter, J. C. Ann. Chim. 1960, 5, 415.

25. Bachstetz, M. Ber. 1930, 63B, 1000 [Chem. Abst. 1930, 24, 3760].

26. Shugar, D.; Jack, J. F. Biochem. Biophys. Acta. 1952, 9, 199.

27. Chargaff, E.; Davidson, J. N. The Nucleic Acids 1; Academic Press, Inc.: New York, N.Y, 1955; p. 113.

28. Woodward, R. B. J. Amer. Chem. Soc. 1942, 64, 72.

29. Petel, D. R.; Choxi, C. S.; Petel, S. P. Can. J. Chem. 1969, 47, 105.

30. Cohen, M. D.; Fisher, E. J. Chem. Soc. 1962, 3044.

31. Masoud, M.S.; El Dessoukey, M.A.; Haggag, S.S. Spectroscopy Lett. 1985, 18, 251.

32. Katritzky, A. R.; Maine, F. W. Tetrahedron, 1964, 20, 299.

33. Bitz, H. Berichte, 1905, 38, 1418.

34. Krouth, W. Bericht über Patente. 1896, p. 77.

35. Hunt, R. R.; McOmie, J. F. W.; Sayer, E. R. J. Chem. Soc. 1959, 527.

36. Britton, T. S. Hydrogen Ions; Chapman and Hall Ltd: London, 1955.

Sample Availability: Samples are available from the authors.

(C) 2002 by MDPI (http://www.mdpi.org). Reproduction is permitted for noncommercial purposes 